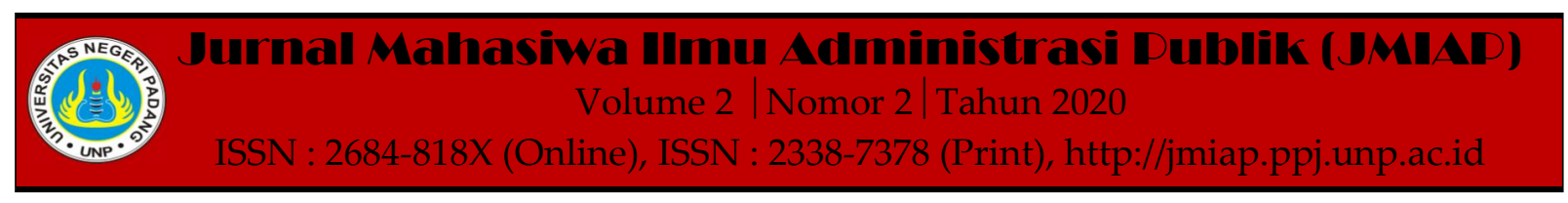

\title{
IMPLEMENTASI STRATEGI BALAI LATIHAN KERJA (BLK) PADANG DALAM MENINGKATKAN KUALITAS TENAGA KERJA
}

\author{
Yana Restu Winanda ${ }^{1(a)}$, Adil Mubarak ${ }^{2(b)}$ \\ ${ }^{1}$ Jurusan Ilmu Administrasi Negara, Universitas Negeri Padang \\ ${ }^{2}$ Jurusan Ilmu Administrasi Negara, Universitas Negeri Padang \\ a)yanarestuwinanda02@gmail.com, ${ }^{b)}$ adilmubarak@fis.unp.ac.id
}

\begin{abstract}
This study describes the implementation strategy of the Balai Latihan Kerja (BLK) Padang in improving the quality of labor. For conduct Competency Based Training (PBK) in order to improve the quality of the workforce, the strategies that have been set must be realized with good implementation. This research was conducted using the method qualitative descriptive. The selection of informants was carried out using a purposive technique sampling, test the validity of the data using triangulation techniques. Data collection conducted by interview and documentation study. Data analysis technique done by data reduction, data presentation, data verification. Results research shows that the implementation of strategy Balai Latihan Kerja (BLK) Padang in improving the quality of labor can be said to have already pretty well implemented. Implementation of this strategy when viewed from theory Amir has been carried out starting from who carried out, how managing the program, the budget needed, making procedures for ensure implementation and how to implement the strategy the. Although in its implementation there are still shortcomings and obstacles encountered.
\end{abstract}

Keywords : Implementation, Strategy, Training, Labor

Corresponding author. Email.yanarestuwinanda02@gmail.com, adilmubarak@fis.unp.ac.id How to cite this article. Winanda, Y. Restu \& Mubarak, A. (2020). Implementasi Strategi Balai Latihan Kerja (BLK) Padang dalam Meningkatkan Kualitas Tenaga Kerja. Jurnal Mahasiwa Ilmu Administrasi Publik (JMIAP) Jurusan Ilmu Administrasi Negara Fakultas Ilmu Sosial Universitas Negeri Padang, Volume 2 (2), Hal. 18-25.

http://jmiap.ppj.unp.ac.id

ISSN : 2684-818X (Online), ISSN : 2338-7378 (Print)

Copyright $(2020$. Published by Pusat Kajian-Pemberdayaan dan Pelayanan Masyarakat (PK-P2M) FIS UNP Padang 


\section{PENDAHULUAN}

Indonesia kaya dengan sumber daya, baik yang alam maupun manusia, tetapi saat ini jumlah sumber daya alam terus berkurang dan terbatas berbeda dengan sumber daya manusia yang senantiasa bertambah setiap tahunnya. Jumlah penduduk Indonesia terbanyak di ASEAN. Tahun 2019, Indonesia diproyeksikan jumlah penduduknya mencapai 266,91 juta jiwa atau sama dengan sepertiga total penduduk di ASEAN. Jumlah penduduk yang terus meningkat juga akan meningkatkan angkatan kerja. Pesatnya perkembangan bisnis dan persaingan pasar saat ini menjadi PR besar bagi pemerintah Indonesia untuk meningkatkan mutu hasil produksi serta jasa. Untuk itu Sumber Daya Manusia yang berkualitas menjadi bekal untuk menghadapi persaingan.

Data yang diperoleh dari Badan Pusat Statistik (BPS) Sumatera Barat pada Februari 2019, jumlah angkatan kerja di Sumatera Barat sebanyak 2,69 juta orang dengan penduduk yang bekerja berjumlah 2,54 juta orang dan sebanyak 142,24 ribu orang pengangguran. Meskipun angka Tingkat Pengangguran Terbuka (TPT) turun dari tahun sebelumnya sebesar $0,26 \%$ tapi angka ini masih terbilang cukup tinggi dikarenakan setiap tahunnya jumlah lulusan pendidikan sekolah terus meningkat. TPT pada Februari 2019 berdasarkan tingkat pendidikan didominasi oleh lulusan Diploma I/II/III dan lulusan Sekolah Menengah Umum (SMA Umum) sebesar 10,86 persen dan 7,80 persen.

\section{Gambar 1. TPT Menurut Tingkat Pendidikan Tertinggi}

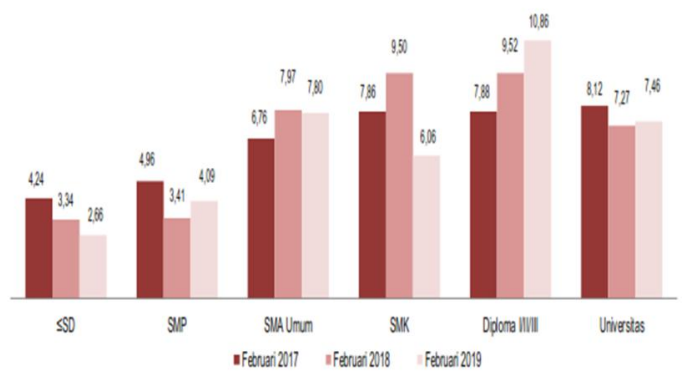

Sumber: BPS Sumbar
Tenaga kerja di Sumatera Barat yang terserap masih didominasi oleh penduduk berpendidikan rendah (SMP ke bawah) sebanyak 1,34 juta orang (52,75\%). BPS Sumbar menyatakan bahwa orang yang berpendidikan rendah cenderung mau melakukan pekerjaan apa saja. Hal ini juga terlihat dari tingginya persentase pekerja informal sebesar $62,29 \%$ dibandikan pekerja formal sebesar $37,71 \%$. Menurut kajian evaluasi pembangunan yang dilaksanakan oleh Badan Perencanaan Pembangunan Nasional (BAPPENAS) sektor informal memiliki karakteristik seperti jumlah unit usaha banyak dalam skala kecil, kepemilikan oleh individu dan keluarga, rendahnya tingkat pendidikan keterampilan dan produktivitas serta tingkat upah yang relatif rendah dibandingkan sektor formal.

Untuk mewujudkan tenaga kerja kompeten dan berdaya saing di Sumatera Barat perlunya pelatihan keterampilan dalam rangka meningkatkatkan kualitas tenaga kerja sehingga lebih profesional dan mampu menciptakan lapangan pekerjaan sendiri. Menyikapi persoalan di atas, Kementerian Ketenagakerjaan Republik Indonesia mencari jalan keluar untuk mengatasi persoalan tersebut melalui pendidikan vokasi Balai Latihan Kerja (BLK) salah satunya Balai Latihan Kerja Padang (BLK) Padang. Sebagai bagian utama dari unsur pemerintah maka ada tiga fungsi hakiki yang harus dijalankan yaitu fungsi pelayanan, fungsi pemberdayaan dan fungsi pembangunan (Adil Mubarak, 2014) yang sejatinya jika program pelatihan di BLK untuk mewujudkan tenaga kerja berkualitas ini efektif maka pemerintah telah menjalankan fungsinya secara menyeluruh. BLK ini menjadi tempat penyelenggaraan proses pelatihan kerja untuk memperoleh kompetensi kerja tertentu sebagai bekal dalam memasuki pasar kerja. Namun saat ini lulusan dari Balai Latihan Kerja (BLK) Padang, dalam database yang diperoleh di tahun 2019 dari bulan Januari hingga Desember, dari 1.930 siswa yang mengikuti pelatihan yang 
bekerja saat ini terdata hanya 132 orang atau hanya $6,8 \%$ yang terserap pasar kerja.Dan masih adanya keluhan yang diterima oleh bagian pemberdayaan BLK Padang terkait siswanya yang kurang disiplin saat magang. Kemudian kurangnya sumber daya dan sarana prasarana yang dimiliki BLK Padang. Dari permasalahan tersebut perlunya dilihat bagaimana implementasi strategi yang dilakukan oleh BLK Padang dalam memberikan pelatihan untuk meningkatakan kualitas tenaga kerja dan kendala yang dihadapi.

\section{TINJAUAN PUSTAKA}

\section{Konsep Implementasi}

Menurut Van Meter dan Van Horn (Umar, 2017) merumuskan bahwa proses implementasi sebagai "those actions by public or private individuals (or group) that are directed at the achievement of objectives set forth in prior policy decisions". Maknanya ialah bahwa implementasi mengandung pengertian tindakan yang dilakukan individu atau pejabat maupun swasta yang mengarah pada tujuan yang ditetapkan.

Dalam mencapai tujuan dan kesepakatan program yang telah dirumuskan, Implementasi menjadi instrumen paling penting bagi pemerintah sebagai implementator. Dengan kata lain keberhasilan program yang telah dirumuskan tergantung kepada implementasinya dan efek yang didapatkan dari implementasi program tersebut. (Mubarak, 2012).

Jadi dalam proses kebijakan, implementasi menjadi langkah atau aspek yang sangat penting dalam mencapai tujuan yang ditetapkan. Implementasi diarahkan pada realisasi program yang telah dirumuskan sebagai penentu keberhasilan dan kegagalan serta peluang dan hambatan yang ada ketika sebuah organisasi melaksanakan tugas dari program tersebut.

\section{Konsep Strategi}

Strategi berarti memilih cara yang paling efektif dalam mencapai tujuan yang ditetapkan dengan menggunakan sumbersumber perusahaan (Terry, 2013). Hamel dan Prahalad dalam (Rangkuti, 2009) menyatakan bahwa strategi bersifat incremental (senantiasa meningkat) dan terus-menerus dengan melihat apa yang dapat terjadi atau apa yang diharapkan pelanggan di masa mendatang.

Strategi dapat diartikan sebagai tindakan dalam menentukan cara paling efektif untuk mencapai tujuan dengan melihat apa yang dapat terjadi kedepannya dan memanfaatkan sumber-sumber yang ada.

\section{Strategi Balai Latihan Kerja (BLK) Padang}

Berdasarkan landasan kebijaksanaan dalam Renstra BLK Padang tahun 20192020, strategi pokok pengembangan pelatihan kerja dan produktivitas tenaga kerja melalui pelatihan guna meningkatkan daya saing tenaga kerja dalam rangka mencapai tujuan pembangunan ketenagakerjaan Indonesia adalah mewujudkan peningkatan pembinaan dan pengembangan pelatihan. Strategi pembinaan pelatihan dan pengembangan dirinci menjadi empat strategi yaitu:

a. Peningkatan kualitas sumber daya pelatihan dan pengembangan;

b. Penguatan sistem dan metode pelatihan dan uji kompetensi;

c. Penguatan sistem jejaring dan pendanaan pelatihan;

d. Revitalisasi kinerja kelembagaan dan pengembangan SDM pelatihan.

\section{Konsep Implementasi Strategi}

Implementasi strategi merupakan serangkaian kegiatan untuk mengeksekusi perencanaan strategik dengan kata lain strategi yang dirumuskan diterapkan dalam berbagai program kerja, anggaran, dan prosedur (Amir, 2012).

Dalam mengimplementasikan strategi, melihat dari aspek-aspek sebagai berikut(Amir, 2012).

a. Siapa yang mengimplementasikan?

Tentang siapa yang akan mengimplementasikan strategi yang sudah dirumuskan. 
b. Apa yang akan dilakukan

Untuk mengimplementasikan strategi, perusahaan memerlukan rumusan program, anggaran yang akan membiayai pelaksanaan program, dan prosedur untuk memastikan program berjalan seperti yang diharapkan.

c. Bagaimana

Strategi

Diimplementasikan

Agar semua pekerjaan dalam implementasi dapat berjalan mulus, perusahaan perlu mengorganisasi semuanya dengan tepat.

Jadi, Implementasi strategi merupakan aktivitas yang menempatkan strategi yang telah diformulasikan menjadi sebuah tindakan. Implementasi strategi juga harus memperhatikan siapa aktor yang akan melaksanakan dan dalam strategi tersebut apa saja yang harus dilakukan serta menetapkan cara yang tepat untuk mengoordinasikan antar tindakan yang dilaksanakan.

\section{Konsep Tenaga Kerja}

Tenaga kerja dalam UU No 13 Tahun 2003 menjelaskan bahwa setiap orang yang mampu melakukan pekerjaan guna menghasilkan barang dan/jasa baik untuk memenuhi kebutuhan sendiri maupun untuk masyarakat. Menurut (Pujoalwanto, 2014), tenaga kerja bermakna pada kemampuan seseorang dalam melakukan aktivitas untuk memenuhi kebutuhannya. Jadi, dapat diartikan bahwa tenaga kerja merupakan seseorang yang memenuhi kebutuhan hidupnya dengan mengandalkan kemampuan bekerja yang dimilikinya untuk menghasilkan barang atau jasa.

Tenaga kerja sebagai sumber daya manusia yang memiliki peran penting dalam mencapai tujuan organisasi harus mempunyai kualitas yang baik untuk mendapatkan kualitas kerja yang terbaik juga. Menurut Matutina dalam (Leuhery, 2018), kualitas sumber daya manusia mengacu pada pengetahuan (knowledge), keterampilan (skill), dan abilities.

\section{METODE PENELITIAN}

Penelitian ini kualitatif yang bersifat deskriptif. Lokasi penelitian ini dilaksanakan di Kantor BLK Padang. Penentuan informan menggunakan metode purposive sampling yaitu memilih informan yang dianggap mengetahui informasi masalah secara mendalam. Adapun informan dalam penelitian ini adalah Kepala Sub Bagian Tata Usaha BLK Padang, Kepala Seksi Program dan Evaluasi BLK Padang, Kepala Seksi Penyelenggaraan BLK Padang, Kepala Seksi Pemberdayaan BLK Padang, dan staf BLK Padang serta peserta lulusan pelatihan BLK Padang. Pengumpulan data dilakukan dengan wawancara dan studi dokumentasi. Teknik triangulasi digunakan untuk menguji keabsahan data.

\section{HASIL DAN PEMBAHASAN \\ Implementasi Strategi BLK Padang dalam Meningkatkan Kualitas Tenaga Kerja}

Balai Latihan Kerja (BLK) Padang dalam menetapkan strategi berpegang kepada dasar hukum Undang-Undang Republik Indonesia No 13 Tahun 2003 tentang Ketenagakerjaan dan Peraturan Menteri Ketenagakerjaan Republik Indonesia Nomor 21 Tahun 2015 Tentang Organisasi Dan Tata Kerja Unit Pelaksana Teknis Bidang Pelatihan Kerja.

Konsep implementasi strategi menurut (Amir, 2012) memiliki aspek-aspek dalam pengimplementa-siannya, dimana implementasi strategi merupakan serangkaian aktivitas yang dibutuhkan untuk mengeksekusi sebuah strategi yang telah ditetapkan. Implementasi strategi BLK Padang dalam meningkatkan kualitas tenaga kerja adalah sebagai berikut:

a. Siapa yang mengimplementasikan.

Dalam mengimplementasikan strategi yang telah dirumuskan, Balai Latihan Kerja (BLK) Padang bergantung dengan skala organisasi dan struktur yang ada, sub bagian 
tata usaha peningkatan sumber daya yang ada di BLK Padang dan tiga seksi yang saling berkaitan yaitu seksi program dan evaluasi yang mempunyai tugas untuk melakukan penyusunan rencana, program, anggaran, penyusunan bahan berdasarkan standar yang di tetapkan oleh Kementerian Ketenagakerjaan RI dan pelaksanaan evaluasi dari kegiatan pelatihan yang telah diadakan. Selanjutnya seksi penyelenggaraan, yang bertugas untuk melakukan pelaksanaan dari semua kegiatan pelatihan dan uji kompetensi. Dan selanjutnya seksi pemberdayaan, yang bertugas untuk melakukan konsultasi, promosi dan kerjasama dengan kelembagaan pelatihan. Serta instruktur sebagai tenaga pelatih yang memberikan materi teori dan praktek kepada peserta yang mengikuti pelatihan.

\section{b. Apa yang akan dilakukan}

Balai Latihan Kerja Padang dalam mengimplementasikan strategi sudah memiliki program, anggaran dan prosedur untuk memastikan strategi bisa berjalan dengan baik.

1) Program

Strategi Balai Latihan Kerja (BLK) Padang memiliki programdalam pengimplemen- tasiannya, agar program sesuai dengan pengembangan pasar atau kebutuhan industri, BLK Padang melakukan training need analysis (TNA) atau analisis kebutuhan pelatihan, apa yang menjadi kebutuhan masyarakat. Dalam meningkat- kan kualitas tenaga kerja, saat ini program pelatihan yang ada di BLK Padang untuk menambah keterampilan tenaga kerjayaitu Program Reguler dan MTU (Mobile Training Unit). Program reguler ini terdiri dari 12 kejuruan yaitu pariwisata, teknik refrigeration, welding/las, tata kecantikan, teknik elektronika, teknologi informasi dan komunikasi (TIK), teknik manufaktur, garmen apparel, bisnis manajemen, teknik otomotif, teknik listrik dan teknik konstruksi (bangunan).Program ini dibuka untuk masyarakat umum dan pelatihan dilaksanakan di BLK Padang.
Berbeda dengan program reguler, program MTU (Mobile Training Unit) yaitu program yang bekerjasama dengan nagarinagari di Sumatera Barat, pelaksanaan pelatihannya dilakukan di daerah-daerah yang jauh dari pusat kota. Program ini memberikan kesempatan kepada masyarakat yang tidak memiliki akses terhadap pelatihan ke BLK. MTU ini pelatihannya langsung dilaku- kan ke nagari yang diusulkan dan nagari setempat nantinya menyediakan tempat.

2) Penganggaran

Balai Latihan Kerja (BLK) Padang untuk merealisasikan sebuah program membutuhkan anggaran. Anggaran kegiatan pelatihan di BLK Padang di biayai oleh Kementerian Ketenagakerjaan RI yang sudah diatur di dalam Surat Edaran Ditjen Binalattas Kementerian Ketenagakerjaan RI tentang Standar Nomenklatur dan Standar Biaya Masukan pada kegiatan pelatihan berbasis kompetensi. Semuanya sudah diatur di dalam surat edaran tersebut. Mulai dari biaya honor tim asesor, fasilitas peserta pelatihan dan anggaran bahan pelatihan semua sudah diatur di dalamnya dan BLK Padang menyesuaikan dengan standar yang telah diberikan oleh pusat untuk kegiatan pelatihan.

3) Prosedur

Balai Latihan Kerja (BLK) Padang dalam pelaksanaan pelatihan ini berpedoman kepada SOP yang telah ditetapkan. Untuk SOP Pendaftaran pelatihan mendapat respon yang positif dari peserta pelatihan ketika mendaftar di BLK Padang karena efektif dan tidak berbelitbelit.

4) Bagaimana Strategi Diimplementasikan

Bagaimana strategi diimplementasikan oleh Balai Latihan Kerja (BLK) Padang agar dapat berjalan dengan mulus adalah sebagai berikut:

1) Peningkatan kualitas sumber daya pelatihan dan pengembangan

Program pelatihan berbasis komptensi yang ada di BLK Padang bertujuan untuk 
menambah kompetensi peserta pelatihan. Banyak peserta pelatihan sebelumnya tidak punya keterampilan akhirnya memiliki keterampilan baru setelah mengikuti pelatihan di BLK Padang. BLK Padang selalu mengembangkan pelatihan berkenaan dengan kemajuan teknologi. Dan BLK Padang setiap tahunnya mengadakan upgrading dalam rangka untuk meningkatkan kualitas instruktur dibidangnya masing-masing. Syarat seorang instruktur di BLK Padang harus bersertifikasi kompetensi dibidang teknis dan metodologi. Namun masih ada beberapa instruktur di BLK Padang yang kurang dalam metodologinya, dalam transfer ilmu kepada peserta pelatihan. Dan untuk peningkatan kualitas peralatan, BLK Padang setiap tahun meng-upgrade peralatan yang disesuaikan dengan kebutuhan industri. Peralatan yang rusak akan diperbaiki sesuai dengan anggaran yang ada.

2) Penguatan sistem dan metode pelatihan dan uji kompetensi.

Menurut Matutina (dalam Leuhery, 2018), kualitas sumber daya manusia mengacu pada 3 hal yaitu knowledge, skill, abilities. Dalam meningkatkan kualitas tenaga kerja, BLK Padang mempunyai 3 unsur dalam memberikan pelatihan yaitu knowledge, skill, dan attitude. Untuk memperkuat sistem, BLK Padang melakukan seleksi terhadap calon siswa pelatihan sebelum mengikuti pelatihan. Seleksi tersebut terbagi 2 yaitu seleksi tertulis dan wawancara dari konsultan psikologi untuk melihat motivasi dari calon siswa pelatihan. Metode pelatihannya, setiap hari pelatihan mengenai attitude, BLK Padang melakukan pembinaan sikap atau PBB dengan TNI/Polri mengenai sikap mental dan disiplin. Kegiatan pembinaan sikap ini sangat bagus untuk melatih disiplin peserta pelatihan. Bagi peserta yang datang terlambat tidak diizinkan untuk mengikuti pelatihan pada hari yang bersangkutan.

Selanjutnya dalam memberikan materi pelatihan di dalam kelas $20 \%$ teori dan $80 \%$ praktek. Karena kegiatan pelatihan ini berbasis kompetensi maka pelatihannya lebih banyak praktek terkait kejuruan yang diikuti peserta. Kemudian setelah peserta mengikuti kegiatan pelatihan di BLK Padang atau off the job training, selanjutnya peserta melaksanakan on the job training (OJT) atau magang di tempat kerja. Namun kegiatan OJT ini hanya sampai bulan September saja, bagi peserta pelatihan di bulan Oktober, November, Desember tidak mendapatkan OJT karena keterbatasan dana yang dianggarkan untuk OJT ini hanya sampai bulan september.

Terkait dengan uji kompetensi dilakukan jika peserta pelatihan mengikuti SOP pelatihan hingga lulus, jika ada OJT atau magang maka peserta pelatihan harus menyelesaikan magangnya terlebih dahulu baru diperbolehkan untuk mengikuti uji kompetensi. Namun, jika OJT tidak ada maka langsung melakukan uji kompetensi. BLK Padang memiliki Lembaga Sertifikasi Profesi Pihak Kedua (LSP-P2) yang bertanggung jawab melaksanakan uji kompetensi dan sertifikasi kompetensi profesi berdasarkan SK No: BNSP-LSP963-ID dengan mempunyai 122 asesor diberbagai bidang. Peserta pelatihan yang lulus uji kompetensi akan diberikan sertifikat kompetensi namun jika tidak lulus dalam uji kompetensi maka tidak diberikan sertifikat kompetensi.

3) Penguatan sistem jejaring dan pendanaan pelatihan

Penguatan sistem jejaring dan pendanaan dalam implementasinya BLK Padang berusaha menyalurkan tenaga kerja kepada jejaring Disnakertrans Prov.Sumbar dan Disnaker Kota Padang serta perusahaan-perusahaan atau industri. BLK Padang memfasilitasi untuk penyaluran tenaga kerja dengan mempertemukan antara perusahaan dengan pencari kerja. Saat ini perusahaan mitra BLK Padang sudah berjumlah 195 perusahaan.

Terkait dengan pendanaan pelatihan di BLK Padang yang dibiayai oleh Kementerian Ketenagakerjaan RI. Segala 
fasilitas untuk pelatihan sudah diatur oleh Kemenaker. Kemudian BLK Padang yang menyusun pendanaan berdasar- kan standar yang diberikan oleh pusat. Dalam kegiatan pelatihan, peserta pelatihan tidak dipungut biaya apapun, peserta mendapatkan uang transportasi pelatihan, uang transportasi magang, makan siang, baju, modul, dan alat-alat pelatihan sesuai kejuruan yang diikuti.

4) Revitalisasi kinerja kelembagaan dan pengembangan SDM pelatihan

Strategi BLK Padang terkait revitalisasi kinerja kelembagaan dan pengembangan SDM pelatihan dalam implementasinya melakukan revitalisasi sesuai dengan kebutuhan masyarakat dan industri. Setiap tahunnya menambah alat-alat yang sifatnya terbaru. Gedung-gedung sejak 2013 mulai direnovasi yang kurang maksimal, dan saat ini BLK Padang sedang membangun gedung workshop Fashion Technology. Untuk pengembangan SDM pada saat tertentu melakukan pelatihan untuk peningkatan kompetensi (upgrading) instruktur dari Bina Intala yang merupakan satuan kerja yang berada dibawah Direktorat Jenderal Pelatihan dan Produktivitas, Kemnaker.

Setiap tahun BLK Padang juga melakukan evaluasi terhadap keefektifan kegiatan pelatihan dengan cara menyebarkan kusioner evaluasi program pelatihan kepada peserta setiap selesai pelatihan. Hal yang dievaluasi mulai dari instruktur, sarana prasarana dan pelayanannya.

\section{Kendala yang Dihadapi untuk Mengimplementasikan Strategi BLK Padang dalam Meningkatkan Kualitas Tenaga Kerja}

Kendala yang dihadapi BLK Padang dalam mengimplementasikan strategi BLK Padang adalah kesadaran masyarakat untuk merubah mindset masih kurang peduli. Pemahaman masyarakat bahwa pentingnya sebuah kompetensi masih rendah karena dianggap belum menjadi sebuah kebutuhan.
Padahal menurut (Febriani, 2013) kualitas tenaga kerja dilihat dari keahlian dan keterampilan yang mampu bersaing dengan tenaga kerja dari manapun.

Kemudian sosialisasi ke masyarakat di tingkat kecamatan dan kelurahan masih kurang dikarenakan ketika dilakukan pertemuan banyak diwakilkan ke staf lain sehingga setelah pertemuan tidak ada koordinasi dengan bagian pemberdayaan di tingkat kecamatan dan kelurahan. Kendala lainnya yang dihadapi yaitu terkait dengan pendataan dari siswa pelatihan yang sudah bekerja. Dari 1.930 siswa pelatihan di tahun 2019 yang terdata bekerja hanya 132 orang. Salah satu kendalanya adalah sulitnya untuk menghubungi siswa pelatihan yang sudah lulus untuk mengkonfirmasi apakah siswa yang bersangkutan sudah bekerja atau belum.

\section{PENUTUP}

Implementasi Strategi Balai Latihan Kerja (BLK) Padang dalam meningkatkan kualitas tenaga kerja sudah cukup baik. Siapa yang mengimplementasikan sudah berdasar- kan pada struktur organisasi yang ada di BLK Padang. Strategi yang dirumuskan diimplementasikan dengan program pelatihan yang disesuaikan dengan kebutuhan masyarakat dan dibiayai sepenuhnya oleh Kementerian Ketenagakerjaan RI. Setiap kegiatan sudah dilaksanakan sesuai dengan prosedur yang telah ditetapkandan cukup efektif bagi calon siswa yang mendaftar. Bagaimana strategi yang diimplementasikan sudah cukup baik, terbukti dari kepuasan siswa pelatihan yang mendapatkan keterampilan baru untuk menjadi bekal mereka bersaing di pasar kerja. Pelatihan yang diberikan oleh BLK Padang sudah sesuai dengan unsur yang dibutuhkan untuk meningkatkan kualitas tenaga kerja sebagai sumber daya manusia yaitu knowledge, skill, dan attitude. Namun masih ada keluhan dari siswa pelatihan terkait dengan instruktur yang masih kurang dalam penyampaian materi dan masih ada peralatan yang kurang dibagian sub jurusan surveyor sehingga 
penggunaannya harus bergantian. Kemudian kesempatan On The Job Training (OJT) yang tidak merata didapatkan oleh siswa pelatihan. On TheJob Training (OJT) hanya dilakukan sampai bulan September karena keterbatasan anggaran sehingga siswa yang mengikuti pelatihan di akhir tahun tidak mendapatkan gambaran langsung bagaimana dinamika dunia kerja terkait dengan keterampilan yang diikutinya.

Kendala yang dihadapi untuk mengimplementasikan strategi adalah kurangnya kesadaran masyarakat bahwa kompetensi itu sangat dibutuhkan. Kemudian sosialisasi yang dilakukan di tingkat kecamatan dan kelurahan kurang terlaksana dengan baik karena ketika dilakukan pertemuan banyak yang mewakilkan dengan staf lain sehingga sosialisasi tidak sampai kepada masyarakat. Dan kendala lainnya yaitu sulitnya menghubungi siswa pelatihan untuk mendeteksi apakah sudah bekerja atau belum.

\section{DAFTAR KEPUSTAKAAN}

Adil Mubarak. (2014). Peran Ormas dalam Menjalankan Fungsi Pemerintah Bidang Pemberdayaan. Seminar Nasional UT 2014, 23 Oktober 2014, Universitas Terbuka Convention Center (UTCC). http://repository.ut.ac.id/5102/
Amir, T. M. (2012). Manajemen Strategik. Rajawali Pers.

Febriani. (2013, Desember). Kualitas Pendidikan dan Keterampilan Tenaga Kerja Indonesia, Menuju kesetaraan Upah di Luar Negeri. Jurnal Ekonomi Pembangunan, Vol 14, No 2.

Leuhery, F. (2018). Pengaruh Kualitas Sumber Daya Manusia, Disiplin Kerja, dan Pengembangan Karir terhadap Prestasi Kerja Pegawai Dinas Perhubungan Provinsi Maluku. Jurnal Sosoq, Vol 6, Nol.

Mubarak, A. (2012). Model Impelementasi Program dalam Upaya Pencapaian Sasaran MDGs 2015 (Strategi Bagi Birokrasi Sebagai Ujung Tombak Implementasi 8 sasaran MDGs). Universitas Terbuka, 1-14.

Pujoalwanto, B. (2014). Perekonomian Indonesia; Tinjauan Pustaka, Teoritis, dan Empiris. Graha Ilmu.

Rangkuti, F. (2009). Analisis SWOT Teknik Membedah Kasus Bisnis. PT. Gramedia Pustaka Utama.

Terry, G. R. (2013). Prinsip-prinsip Manajemen. PT. Bumi Aksara.

Umar, Z. (2017). Analisis Implementasi Kebijakan Standar Pelayanan Mininal untuk Peningkatan Kualitas Layanan Publik di Daerah. Jurnal Analisis Dan Kebijakan Publik, Vol 3, No. 